\title{
How Do the Exchange Rates Affect the Sector Indices? A Dynamic Panel Data Analysis for Borsa Istanbul
}

\section{Döviz Kurları Sektör Endekslerini Nasıl Etkiliyor? Borsa İstanbul Üzerine Dinamik Panel Veri Analizi}

\author{
Hande AKSÖZ YILMAZ1 ${ }^{\circledR}$, Fatih GÜZEL ${ }^{2}$ ()
}

\begin{abstract}
This paper aims to investigate the impact of the exchange rate on stock market indices of four main sectors in Turkey. For this purpose, the paper uses monthly data spanning the period between 06/2008-11/2020 and employs the panel GMM estimation method. This method instrumentalizes the past observation values of the dependent variable to control the endogeneity and provides efficient results. Considering that firms operating in many sectors in Turkey are affected by the volatility of the exchange rate, the paper takes initiative in understanding how stock market indices of four sectors react to the fluctuation in USD and Euro prices. This study contributes to the current literature, performing the panel GMM estimation method, unlike studies that only examine the causality relationship on the link between exchange rate and the stock market. The results show that there is unidirectional causality from the exchange rate to stock market indices. According to our findings, the USD/TRY exchange rate negatively affects stock market indices, and the Euro/TRY exchange rate positively affects stock market indices. The findings obtained from the analysis results confirm prior knowledge acquired from Turkey's foreign trade structure.
\end{abstract}

Keywords: Stock market indices, Exchange rate, GMM estimation method

JEL Classification: C23, F31, F32

\section{öz}

Bu makale, döviz kurunun Türkiye'deki dört ana sektörün borsa endeksleri üzerindeki etkisini incelemeyi amaçlamaktadır. Bu amaçla, makale 06/2008-11/2020 dönemini kapsayan aylık verileri kullanmakta ve verimli sonuçlar sunan panel GMM tahmin yöntemini kullanmaktadır. GMM tahmin yönteminde, bağımlı değişkenin geçmiş gözlem değerleri kullanılarak değişkenler arasındaki içsel ilişki kontrol edilebilmektedir. Türkiye'de farklı sektörlerde faaliyet gösteren firmaların döviz kurundaki oynaklıktan etkilendiği göz önüne alındığında; makale, dört sektörün borsa endekslerinin ABD Doları ve Euro fiyatlarındaki dalgalanmaya nasıl tepki verdiğini anlamaya çalışmaktadır. Bu

\begin{abstract}
${ }^{1}$ Dr., Kirsehir Ahi Evran University, Faculty of Economics and Administrative Sciences, Department of Economics, Kirsehir, Turkey

${ }^{2}$ Dr., Kirsehir Ahi Evran University, Faculty of Economics and Administrative Sciences, Department of Business Administration, Kirsehir, Turkey
\end{abstract}

ORCID: H.A.Y. 0000-0002-1115-7535; F.G. 0000-0002-4153-3933

\section{Corresponding author:} Hande AKSÖZ YILMAZ,

Kirsehir Ahi Evran University, Faculty of Economics and Administrative Sciences, Department of Economics, Kirsehir, Turkey E-mail: hande.yilmaz@ahievran.edu.tr

Submitted: 12.07.2021

Revision Requested: 19.09.2021 Last Revision Received: 23.09.2021 Accepted: 11.10.2021

Citation: Aksoz Yilmaz, H., \& Guzel, F. (2021). How do the exchange rates affect the sector indices? A dynamic panel data analysis for Borsa Istanbul. Istanbul Iktisat Dergisi - Istanbul Journal of Economics, 71(2), 411-434.

https://doi.org/10.26650/ISTJECON2021-970320 
çalışma, sadece döviz kuru ile borsa arasındaki bağlantı üzerinden nedensellik ilişkisini inceleyen çalışmaların yanı sıra panel GMM tahmin yöntemini uygulayarak güncel literatüre katkı sağlamaktadır. Sonuçlar döviz kurundan borsa endekslerine doğru tek yönlü bir nedensellik olduğunu göstermektedir. Bulgulara göre, Dolar/TL döviz kuru borsa endekslerini olumsuz etkilemekte ve Euro/TL döviz kuru borsa endekslerini olumlu etkilemektedir. Analiz sonuçlarından elde edilen bulgular, Türkiye'nin dış ticaret yapısından elde edilen ön bilgileri doğrulamaktadır.

Anahtar kelimeler: Borsa endeksi, Döviz kuru, Gmm tahmin yöntemi

JEL Sınıflaması: C23, F31, F32 


\section{Introduction}

The globalization process, which was accelerated in the 1980s and 1990s, has given investment instruments a global character. The volume of international trade and transactions has increased with liberalized markets and technological developments and the dependence, transitivity and sensitivity between financial markets has increased. With an increase in the level of integration, various factors have become more important. The relationship between exchange rates and stock markets has become one of the increasingly important factors in this sense.

Understanding the relationship between exchange rates and stock markets is important for policymakers and investors in the changing global financial atmosphere. Understanding this relationship provides benefits in several ways. First, when the foreign currency is included in portfolios as an investment tool, more effective portfolios can be created. Second, the risks arising from the exchange rate can be anticipated in advance and measures can be taken by decision-makers. Third, the interaction between exchange rates and stock markets can be used to predict future trends. Finally, economic and financial policymakers and regulators can refer to this relationship to formulate appropriate policies (Yıldız, 2014; Uğur \& Bingöl, 2020).

In finance literature, the relationship between the exchange rate and the stock markets is considered based on the effect of the exchange rate on stock prices. In this context, two theories, the traditional and portfolio balance approaches, have been developed to explain the dependence between the relevant variables. According to the traditional approach (Dornbusch \& Fisher, 1980), with the change of the exchange rate, the international competitive structure and foreign trade balance are affected and a change occurs in the income level of the country and the stock prices of the companies. The traditional approach works differently depending on whether the country is export- or import-oriented. An increase in the value of the national currency in an export-oriented country, or a decrease in the exchange rate, will negatively affect the economy, and it has a negative effect 
on the stock market due to the decrease in the attractiveness of the stocks of exporting countries. The decline in exchange rates creates a positive effect on the stock market in import oriented countries. In the portfolio balance approach based on Branson (1983) and Frankel (1983), it is believed that changes in stock prices can affect the movements in exchange rates through portfolio adjustments (foreign capital inflows/outflows). Therefore, a causality relationship from stock price to exchange rate is valid. An increase in stock prices causes an increase in the demand for money while increasing the investor's wealth. The increase in the demand for money causes the domestic currency to appreciate against foreign currency, causing investors to sell their foreign currency-denominated assets to buy more stocks.

Examining this relationship between the stock market and exchange rates is particularly important for countries with a high current account deficit and that are highly sensitive to foreign capital movements. Turkey has pursued liberalization policies since the 1980s. Most major liberalization movements are seen in capital markets and foreign trade. As of September 2020, Turkey's annual current account deficit was 33.8 billion USD; the foreign trade deficit was 49.9 billion USD in 2020 (www.sbb.gov.tr). Also, when Borsa Istanbul (BIST) investor information is analyzed, it can be seen that the number of domestic and foreign investors and stock investments is very close -almost equal- to each other (www.dunya.com). When the portfolio sizes of domestic and foreign investors are examined, as of 2020, the balance of domestic investors is 186 billion TRY and the balance of foreign investors is 290 billion TRY (www.mkk.com.tr).

In this study, the relationship between stock markets and exchange rates has been analyzed within the framework of BIST main sectors. This paper particularly aims to understand the relationship between exchange rates and the stock market in Turkey's main sectors over the period of 06/2008-11/2020. To achieve this goal, we use data based on stock market indices and the exchange rate of four sectors in Turkey. The main research question is as follows: "What is the impact of the exchange rate on stock market indices in four main sectors in Turkey?" The hypothesis of the paper is constituted as follows: 
- Hypothesis 1: The exchange rate (USD/TRY and Euro/TRY) has an effect on the stock market indices of four main sectors in Turkey over the period of 06/2008-11/2020.

- Hypothesis 2: There is positive causality from Euro/TRY exchange rate to the stock market indices in four main sectors in Turkey over the period of 06/200811/2020.

- Hypothesis 3: There is negative causality from USD/TRY exchange rate to the stock market indices in four main sectors in Turkey over the period of 06/200811/2020.

Based on the explanations above, this paper focuses on the relationship between exchange rate and stock market indices. Put differently, this paper analyses the impact of exchange rates on stock market indices in Turkey. The contributions of the paper to the international economics literature are twofold. First, several empirical studies have been devoted to the single exchange rate rather than USD and Euro exchange rates (Nieh \& Lee, 2001; Aydemir \& Demirhan, 2009; Yıldız, 2014; Keskin Benli, 2015; Naresh, Vasudevan \& Mahalakshmi, 2018). This study reveals the relationship between exchange rates and stock market indices, taking into account the two main exchange rates (USD and Euro). Second, the dynamic panel data models have been chosen since the cause and effect relationship for the underlying issue is generally dynamic over time. It would be appropriate to use the fixed effects estimator to reveal a static relationship between exchange rate and stock market indices. However, the traditional fixed effects estimator is biased when the lagged values of the dependent variable are included in the model as independent variables, and it also does not take into account the problem of possible endogeneity of some dependent variables. Using the Panel GMM estimation method is more convenient because the past value of a dependent variable is the independent variable in our data.

In this paper, the sections after the introduction title are continued as follows: A literature review investigating the links between exchange rates and stock market indices is presented in section 2. Section 3 introduces the methodology, variables, data sources and model, and empirical results are given. Section 4 concludes with findings and some policy recommendations. 


\section{Review of Literature}

The literature on the relationship between exchange rates and stock market index is quite broad. The subject has been studied in many international and national studies. There are studies on the relationship between exchange rate and stock market index for developed, developing and underdeveloped countries. Table 1 provides a summary of the literature studies.

\section{Table 1: Summary of Empirical Literature on the Relation Between Stock Market and Exchange Rate}

\begin{tabular}{|c|c|c|c|}
\hline Authors (year) & Period & Variables & Findings \\
\hline \multicolumn{4}{|c|}{ Panel A: International Studies } \\
\hline Aggarwal (1981) & 1974-1978 & $\begin{array}{l}\text { NYSE, S\&P 500, DC } \\
\text { 500, Effective ER } \\
\end{array}$ & $\begin{array}{l}\text { Positive relationship between SM } \\
\text { (stock market) and ER (exchange rate) }\end{array}$ \\
\hline $\begin{array}{l}\text { Bahmani- } \\
\text { Oskooee \& } \\
\text { Sohrabian (1992) }\end{array}$ & $\begin{array}{l}07: 1973- \\
12: 1988\end{array}$ & $\begin{array}{l}\text { S\&P 500, } \\
\text { EER(effective } \\
\text { exchange rate) }\end{array}$ & $\begin{array}{l}\text { No long-term relationship between } \\
\text { ER and SM. } \\
\text { Short-term causality: SM↔ER }\end{array}$ \\
\hline $\begin{array}{l}\text { Granger, Huang \& } \\
\text { Yang (2000) }\end{array}$ & $\begin{array}{l}3.01 .1986- \\
16.06 .1998\end{array}$ & 9 countries & $\begin{array}{l}\text { ER } \rightarrow \text { South Korea; Philippines } \rightarrow \text { ER; } \\
\text { ER↔ Hong Kong, Malaysia, } \\
\text { Singapore, Thailand, Taiwan; No } \\
\text { causal relationship between ER and } \\
\text { Indonesia, ER and Japan. } \\
\end{array}$ \\
\hline Nieh \& Lee (2001) & $\begin{array}{l}01.10 .1993- \\
15.02 .1996\end{array}$ & $\begin{array}{l}\text { G-7 Countries, ER } \\
\text { (\$), USD Index }\end{array}$ & $\begin{array}{l}\text { No long-term relationship between } \\
\text { ER and SM. In the short-term, ER has } \\
\text { a negative effect on German SM but } \\
\text { positive effect on Canada and UK SM. } \\
\text { SM of Japan and Italy has a negative } \\
\text { effect on ER. }\end{array}$ \\
\hline $\begin{array}{l}\text { Hatemi-J \& } \\
\text { Irandoust (2002) }\end{array}$ & \begin{tabular}{|l|}
$01: 1993-$ \\
$12: 1998$ \\
\end{tabular} & $\begin{array}{l}\text { Sweden, effective } \\
\text { ER basket }\end{array}$ & $\mathrm{SM} \rightarrow \mathrm{ER}$ \\
\hline Tabak (2006) & $\begin{array}{l}01.08 .1994- \\
14.05 .2002\end{array}$ & Brazil, ER (\$) & $\begin{array}{l}\text { No long-term relationship between } \\
\text { ER and SM. Linear causality: SM } \rightarrow \text { ER } \\
\text { (with negative correlation); Non-linear } \\
\text { Causality: ER } \rightarrow \text { SM }\end{array}$ \\
\hline Kutty (2010) & $\begin{array}{l}\text { 01:1989- } \\
12: 2006\end{array}$ & Mexico, ER (\$) & $\begin{array}{l}\text { There is no long-term relationship } \\
\text { between ER and SM. Short-term } \\
\text { causality: SM } \rightarrow \text { ER }\end{array}$ \\
\hline $\begin{array}{l}\text { Caporale et al. } \\
\text { (2014) }\end{array}$ & $\begin{array}{l}\text { 06.08.2003- } \\
28.12 .2011 \\
\text { (weekly) }\end{array}$ & $\begin{array}{l}\text { US, UK, Canada, } \\
\text { Japan, the Euro } \\
\text { area, Switzerland, } \\
\text { EER }\end{array}$ & $\begin{array}{l}\text { US, UK } \rightarrow \text { ER; ER } \rightarrow \text { Canada; the } \\
\text { Eurozone, Switzerland } \leftrightarrow E R \text { ER. } \\
\text { Causality invariance: US } \rightarrow \text { ER; ER } \rightarrow \text { the } \\
\text { Eurozone, Japan; Switzerland, } \\
\text { Canada } \leftrightarrow \text { ER }\end{array}$ \\
\hline $\begin{array}{l}\text { Naresh et al. } \\
(2018)\end{array}$ & $\begin{array}{l}01.01 .2006- \\
23.12 .2015\end{array}$ & $\begin{array}{l}\text { BRICS Countries, } \\
\text { ER (\$) }\end{array}$ & ER has a negative effect on SM. \\
\hline
\end{tabular}




\begin{tabular}{|c|c|c|c|}
\hline Kumar (2019) & $\begin{array}{l}\text { 01:1994- } \\
12: 2015\end{array}$ & India, REER, etc. & $\begin{array}{l}\text { Unidirectional non-linear causality } \\
\text { from ER to SM. }\end{array}$ \\
\hline Gazel (2020) & $\begin{array}{l}\text { 01:2001- } \\
07: 2017\end{array}$ & BRICS, ER (\$), etc. & $\begin{array}{l}\text { ER } \rightarrow \text { Brazil; India and China } \rightarrow \text { ER; South } \\
\text { Africa↔ER; positive components of } \\
\text { ER affects Brazil, Russia and China; } \\
\text { negative components of ER affects } \\
\text { Russia; positive components of India } \\
\text { SM affects ER; negative components } \\
\text { of South Africa SM affects ER. }\end{array}$ \\
\hline \multicolumn{4}{|c|}{ Panel B: Studies on Turkey and BIST 100} \\
\hline $\begin{array}{l}\text { Elmas \& Esen } \\
\text { (2011) }\end{array}$ & $\begin{array}{l}\text { 01:1999- } \\
\text { 03:2010 }\end{array}$ & $\begin{array}{l}\text { Turkey, Germany, } \\
\text { France, the } \\
\text { Netherlands, } \\
\text { Russia, India, ER(\$) }\end{array}$ & $\begin{array}{l}\text { A cointegration relationship between } \\
\text { Russia and ER according to the Engle- } \\
\text { Granger test. There is a cointegration } \\
\text { relationship between Russia, Turkey } \\
\text { and ER according to the Johansen } \\
\text { test. ER } \rightarrow \text { Turkey, Germany, France, } \\
\text { Netherlands; Russia, India } \rightarrow \text { ER }\end{array}$ \\
\hline $\begin{array}{l}\text { Poyraz \& Tepeli } \\
\text { (2014) }\end{array}$ & $\begin{array}{l}\text { 12:1995- } \\
11: 2011\end{array}$ & $\begin{array}{l}\text { BIST 100, ER basket } \\
(\$-€) \text {, etc. }\end{array}$ & $\begin{array}{l}\text { ER negatively affects SM. Short- } \\
\text { term causality: ER } \rightarrow \text { SM; Long-term } \\
\text { causality: } S M \rightarrow E R\end{array}$ \\
\hline $\begin{array}{l}\text { Altınbaş, Kutay, \& } \\
\text { Akkaya (2015) }\end{array}$ & $\begin{array}{l}\text { 01:2003- } \\
07: 2012\end{array}$ & $\begin{array}{l}\text { BIST 100, ER (\$), } \\
\text { etc. }\end{array}$ & $\begin{array}{l}\text { A negative relationship between SM } \\
\text { and ER. } \\
E R \rightarrow S M\end{array}$ \\
\hline $\begin{array}{l}\text { Yüce Akıncı \& } \\
\text { Küçükçaylı (2016) }\end{array}$ & $\begin{array}{l}\text { 07:1997- } \\
12: 2013\end{array}$ & $\begin{array}{l}12 \text { Countries } \\
\text { (Turkey, Australia, } \\
\text { Canada, Denmark, } \\
\text { Japan, Switzerland, } \\
\text { England, Germany, } \\
\text { France, Finland, } \\
\text { Belgium, Austria), } \\
\text { ER (\$), etc. } \\
\end{array}$ & $\begin{array}{l}\text { ER } \rightarrow \text { SM; ER has a negative effect on } \\
\text { SM. }\end{array}$ \\
\hline $\begin{array}{l}\text { Belen \& } \\
\text { Karamelikli (2016) }\end{array}$ & \begin{tabular}{|l|}
$01: 2006-$ \\
$12: 2014$ \\
\end{tabular} & $\begin{array}{l}\text { BIST 100, real ER, } \\
\text { etc. } \\
\end{array}$ & ER has a negative effect on SM. \\
\hline $\begin{array}{l}\text { Görmüş, Yılancı \& } \\
\text { Aydın (2016) }\end{array}$ & $\begin{array}{l}\text { 09:2007- } \\
11: 2015\end{array}$ & $\begin{array}{l}11 \text { developing } \\
\text { countries, REER }\end{array}$ & $\begin{array}{l}\text { REER } \rightarrow \text { Brazil, India, Mexico, Russia, the } \\
\text { Phil ippines; China, Russia, Indonesia } \\
\rightarrow \text { REER (rea l effective exchange rate); } \\
\text { positive and negative components of } \\
\text { Turkey's SM (stock market) affect ER } \\
\text { (exchange rate). }\end{array}$ \\
\hline Aydın (2017) & $\begin{array}{l}\text { 01:1995- } \\
12: 2016\end{array}$ & $\begin{array}{l}\text { Argentina, Brazil, } \\
\text { China, Indonesia, } \\
\text { the Philippines, } \\
\text { Mexico, Turkey, } \\
\text { REER }\end{array}$ & $\begin{array}{l}\text { A bidirectional relationship between } \\
\text { each countries' SM and ER - except } \\
\text { China. Asymmetric causality results } \\
\text { vary for each country. In the case } \\
\text { of Turkey, there is unidirectional } \\
\text { causality from SM to ER for both } \\
\text { negative and positive shocks. }\end{array}$ \\
\hline $\begin{array}{l}\text { Barut, Karaoğlan } \\
\text { \& Karabayır (2017) }\end{array}$ & $\begin{array}{l}01: 2004- \\
10: 2016\end{array}$ & $\begin{array}{l}\text { BIST 100, ER (\$), } \\
\text { etc. }\end{array}$ & ER has a positive effect on BIST 100. \\
\hline $\begin{array}{l}\text { Budak, Cangi \& } \\
\text { Tuna (2017) }\end{array}$ & $\begin{array}{l}01: 2005- \\
12: 2016\end{array}$ & $\begin{array}{l}\text { BIST 100, BIST 50, } \\
\text { BIST 30, ER (\$), etc. }\end{array}$ & $\begin{array}{l}\text { ER has a positive effect on both SM } \\
\text { indices in the long-term. }\end{array}$ \\
\hline
\end{tabular}




\begin{tabular}{|c|c|c|c|}
\hline Polat (2018) & $\begin{array}{l}\text { 01:2000- } \\
04: 2016\end{array}$ & $\begin{array}{l}\text { OECD countries, } \\
\text { ER ( } \$ \text { ) }\end{array}$ & $\begin{array}{l}\text { ER has a positive effect on SM. ER has } \\
\text { an insignificant effect on one country, } \\
\text { positive effect on } 11 \text { countries } \\
\text { (including Turkey), negative effect } \\
\text { on } 7 \text { countries as unitary results. } \\
\text { ER↔Panel; Turkey } \rightarrow \text { ER }\end{array}$ \\
\hline $\begin{array}{l}\text { Uzun \& Güngör } \\
\text { (2017) }\end{array}$ & $\begin{array}{l}\text { 01:2004- } \\
12: 2013\end{array}$ & $\begin{array}{l}50 \text { countries, ER } \\
\text { (\$), etc. }\end{array}$ & $\begin{array}{l}\text { No causal relationship between } \\
\text { SM and ER for three country } \\
\text { groups (developed, developing and } \\
\text { underdeveloped). }\end{array}$ \\
\hline İlarslan (2018) & $\begin{array}{l}01: 2007- \\
12: 2016\end{array}$ & BIST 100, ER (\$, €) & $\begin{array}{l}\text { A negative relationship in the short- } \\
\text { term and positive relationship in the } \\
\text { long-term between SM and ER. }\end{array}$ \\
\hline $\begin{array}{l}\text { Cingöz \& Kendirli } \\
\text { (2019) }\end{array}$ & \begin{tabular}{|l|}
$01: 2006-$ \\
$06: 2018$ \\
\end{tabular} & $\begin{array}{l}\text { BIST 100, ER (\$), } \\
\text { etc. }\end{array}$ & ER↔BIST 100 \\
\hline \multicolumn{4}{|c|}{ Panel C: Studies on BIST Sectoral Indices } \\
\hline Ayvaz (2006) & \begin{tabular}{|l|}
$01: 1997-$ \\
$12: 2004$
\end{tabular} & \begin{tabular}{|l|} 
BIST 100, BIST \\
Services, BIST \\
Financials, BIST \\
Industrials, ER (\$) \\
\end{tabular} & $\begin{array}{l}\text { \$↔BIST 100; } \$ \leftrightarrow \text { BIST Financials; } \\
\text { \$↔BIST Industrials }\end{array}$ \\
\hline $\begin{array}{l}\text { Aydemir \& } \\
\text { Demirhan (2009) }\end{array}$ & $\begin{array}{l}\text { 23.02.2001- } \\
11.01 .2008\end{array}$ & $\begin{array}{l}\text { BIST 100, BIST } \\
\text { Services, BIST } \\
\text { Financials, BIST } \\
\text { Industrials, BIST } \\
\text { Technology, ER (\$) }\end{array}$ & $\begin{array}{l}\text { Bidirectional causality between } \\
\text { ER and all SM indices. There is a } \\
\text { positive causal relationship from } \\
\text { BIST Technology to ER and negative } \\
\text { causality from other indices to ER. }\end{array}$ \\
\hline $\begin{array}{l}\text { Akel \& Gazel } \\
\text { (2014) }\end{array}$ & $\begin{array}{l}01: 2005- \\
12: 2013\end{array}$ & $\begin{array}{l}\text { BIST Industrials, } \\
\text { REER, ER (€), USD } \\
\text { Index (DXY) }\end{array}$ & $\begin{array}{l}\text { A positive long-term relationship } \\
\text { between REER, DXY, } € \text { and BIST } \\
\text { Industrials. There is a positive short- } \\
\text { term relationship between BIST } \\
\text { Industrials and REER, a negative } \\
\text { short-term relationship between \$, } \\
\text { DXY and BIST Industrials. }\end{array}$ \\
\hline Yıldız (2014) & $\begin{array}{l}\text { 01:2010- } \\
09: 2013\end{array}$ & $\begin{array}{l}\text { BIST 100, BIST } \\
\text { Industrials, BIST } \\
\text { Financials, BiST } \\
\text { Services, ER (\$) }\end{array}$ & $\begin{array}{l}\text { A negative relationship between SM } \\
\text { indices except for BIST Financials. } \\
\text { There is a positive relationship } \\
\text { between } \$ \text { and BIST Financials. } \\
\$ \leftrightarrow \text { BIST 100; BIST Technology, BIST } \\
\text { Services, BIST Financials } \rightarrow \text { \$; }\end{array}$ \\
\hline $\begin{array}{l}\text { Keskin Benli } \\
\text { (2015) }\end{array}$ & $\begin{array}{l}\text { 03.01.2005- } \\
26.12 .2013\end{array}$ & $\begin{array}{l}\text { BIST 100, BIST } \\
\text { Industrials, BIST } \\
\text { Financials, BIST } \\
\text { Services, BIST } \\
\text { Technology, ER (\$) }\end{array}$ & $\begin{array}{l}\text { No long-term relationship between } \\
\$ \text { and SM indices. \$ } \leftrightarrow \text { BIST 100, BIST } \\
\text { Technology, BIST Services; BIST } \\
\text { Financials } \rightarrow \text { \$ }\end{array}$ \\
\hline $\begin{array}{l}\text { Ersoy \& Koy } \\
\text { (2016) }\end{array}$ & $\begin{array}{l}\text { 01:2011- } \\
12: 2014\end{array}$ & $\begin{array}{l}\text { BIST Industrials, } \\
\text { BIST Banks, ER } \\
(\$, €)\end{array}$ & $\begin{array}{l}\text { BIST Industrials and BIST Banks } \\
\text { indices have a negative effect on both } \\
\text { ERs. SM indices effect is more on } \$ \\
\text { than } € \text {. }\end{array}$ \\
\hline
\end{tabular}




\begin{tabular}{|c|c|c|c|}
\hline $\begin{array}{l}\text { Eyüboğlu \& } \\
\text { Eyüboğlu (2018) }\end{array}$ & $\begin{array}{l}03.01 .2011- \\
26.05 .2016\end{array}$ & $\begin{array}{l}\text { BIST 100, } 23 \\
\text { sectoral indices, ER } \\
\text { (\$ and } €)\end{array}$ & $\begin{array}{l}\text { A positive long-term relationship } \\
\text { between } € \text {-Textile Leather, } \\
\text { \$-Textile Leather, \$-Retail Trade } \\
\text { and \$-Technology pairs. Both ERs } \\
\text { negatively affect the remaining } \\
\text { sectors in the short-term. } \\
€ \rightarrow \text { Industrials; } € \leftrightarrow \text { BIST 100; \$ BI ST } \\
100 \text {, Industrials, Services. }\end{array}$ \\
\hline Kanat (2018) & \begin{tabular}{|l|}
$01: 2005-$ \\
$12: 2017$ \\
\end{tabular} & $\begin{array}{l}\text { BIST Technology, } \\
\text { ER }(\$, €)\end{array}$ & $\begin{array}{l}\text { \$↔BIST Technology; BIST } \\
\text { Technology } \rightarrow € .\end{array}$ \\
\hline $\begin{array}{l}\text { Akdağ \& Yıldırım } \\
\text { (2019) }\end{array}$ & $\begin{array}{l}01.01 .2000- \\
31.12 .2018\end{array}$ & $\begin{array}{l}\text { BIST Industrials, } \\
\text { BIST Financials, } \\
\text { ER (\$) }\end{array}$ & $\begin{array}{l}\text { \$↔Industrials; } \$ \leftrightarrow \text { Financials; Except } \\
\text { for positive shocks of BIST industrial } \\
\text { and BIST financial indices, both } \\
\text { positive and negative shocks of all } \\
\text { other variables are effective on others. }\end{array}$ \\
\hline $\begin{array}{l}\text { Uğur \& Bingöl } \\
(2020)\end{array}$ & $\begin{array}{l}\text { 04.01.2000- } \\
\text { 25.08.2017 }\end{array}$ & $\begin{array}{l}7 \text { sector indices, ER } \\
\text { basket }(\$-€)\end{array}$ & $\mathrm{SM} \rightarrow \mathrm{ER}$ \\
\hline
\end{tabular}

Notes: $\rightarrow$ represent unidirectional causality; $\leftrightarrow$ represent bidirectional causality between two variables.

When Table 1 is examined, it can be seen that there are empirical studies on both developed and developing countries. Results differ according to the country, exchange rate, period and method examined. For the studies conducted in the private sector of Turkey, the examination of the exchange rate interaction with the main stock index at first will provide information about the overall structure. There is no consensus in the study results related to Turkey (BIST 100), in parallel with international study results. Yüce Akıncı \& Küçükçaylı (2016), Belen \& Karamelikli (2016), Altınbaş et al (2015), Poyraz \& Tepeli (2014) report that there is a negative relationship between stock market and exchange rate. Polat (2018), Barut et al. (2017), Budak et al. (2017) found evidence that shows a positive relationship between stock market and exchange rate.

The second part of the research done on BIST is the studies on the sectors. When the relevant studies are analyzed, it can be seen that there is evidence that there are both negative and positive relationships between the stock market indices and the exchange rate. In summary, the study results are not uniform. When the studies on BIST indices are analyzed, it can be seen that all studies are based on time series analysis. The indexes examined in most of them are limited to the extent that they cannot represent the market as a whole, and the USD is centered as the exchange rate. The current study investigates the interaction 
between BIST main sector indices (BIST Service, BIST Finance, BIST Industry, BIST Technology) and exchange rates (USD and Euro) with a dynamic panel data analysis (GMM). The study is unique in these aspects.

\section{Methodology}

\subsection{Model and Data}

This paper employs the dynamic panel GMM estimation method to analyze the effects of exchange rates on stock market indices of services, financial, industrial, and technology sectors in Turkey. Within this scope, the relevant initial function is presented below:

$\ln \Delta$ Stock Indice $_{t}=f\left(\ln \Delta\right.$ Stock Indice I $_{t-1}, \ln \Delta U S D / T R Y$ Rate $_{i t}, \ln \Delta$ Euro $\left._{\text {TRRY Rate }}{ }_{i t}\right)$

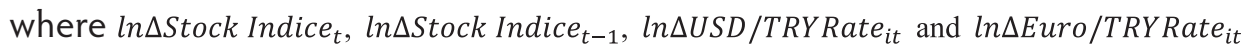
refer to stock indices' changes at month t $\left(\ln \left(\frac{\text { Stock Pricet }}{\text { stock }_{\text {Price }}-1}\right)\right)$ the first lagged value of stock indices, USD/TRY price changes at month $\mathrm{t}\left(\ln \left(\frac{D U S D / T R Y_{t}}{U S D / T R Y_{t-1}}\right)\right)$ and Euro/TRY price

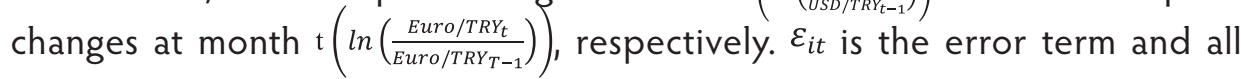
variables are operated in natural logarithmic forms as is represented in Equation (1).

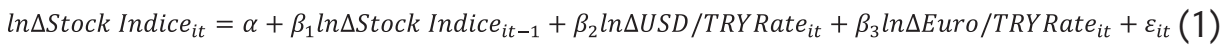

The data set used in this paper adds stock market indices of BIST main sectors (Service, Financial, Industrial, Technology) in Turkey and the monthly data cover the period of 06/2008-11/2020. Sectoral indices' value and exchange rates are extracted from the BIST DataStore and Central Bank of the Republic of Turkey, respectively. If the Balance of Payment Approach is valid, we expect that $\beta_{2}<0$ and $\beta_{3}>0$. Also, the estimates of $\beta_{1}$ can be greater or smaller than zero. 
Figure 1. Stock Market Indices Values of Services Sector

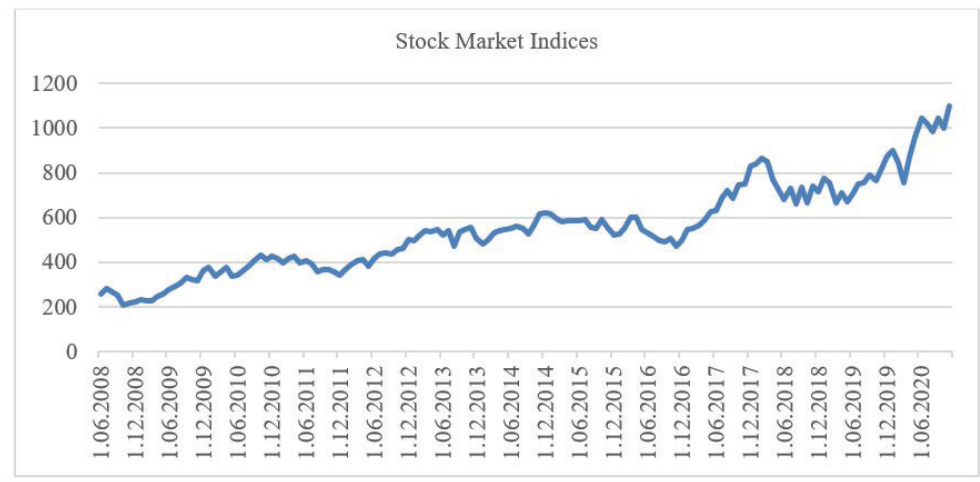

Figure 2. Stock Market Indices Values of Financials Sector

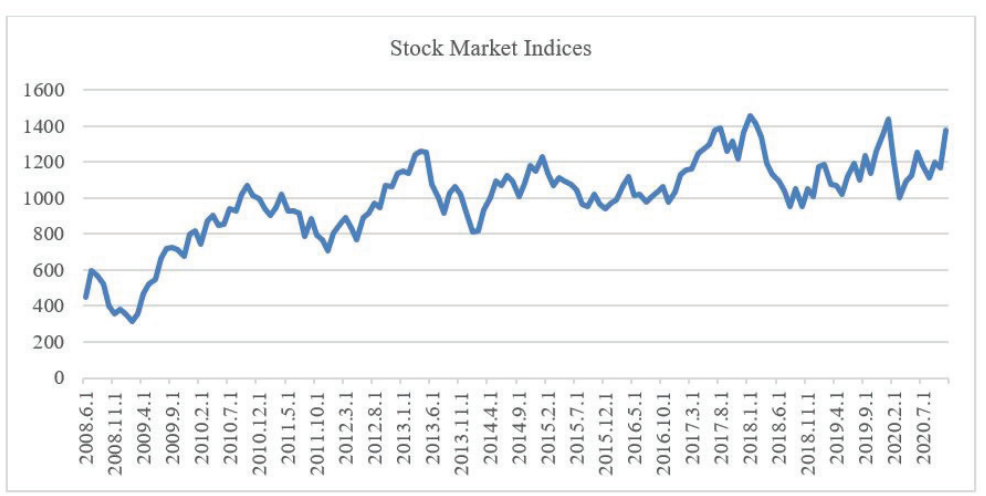

Figure 3. Stock Market Indices Values of Industrial Sector

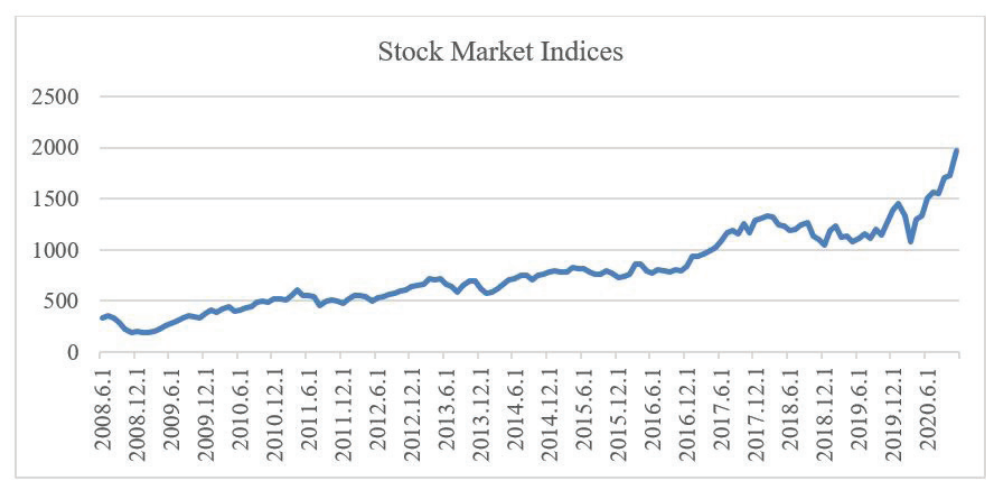


Figure 4. Stock Market Indices Values of Technology Sector

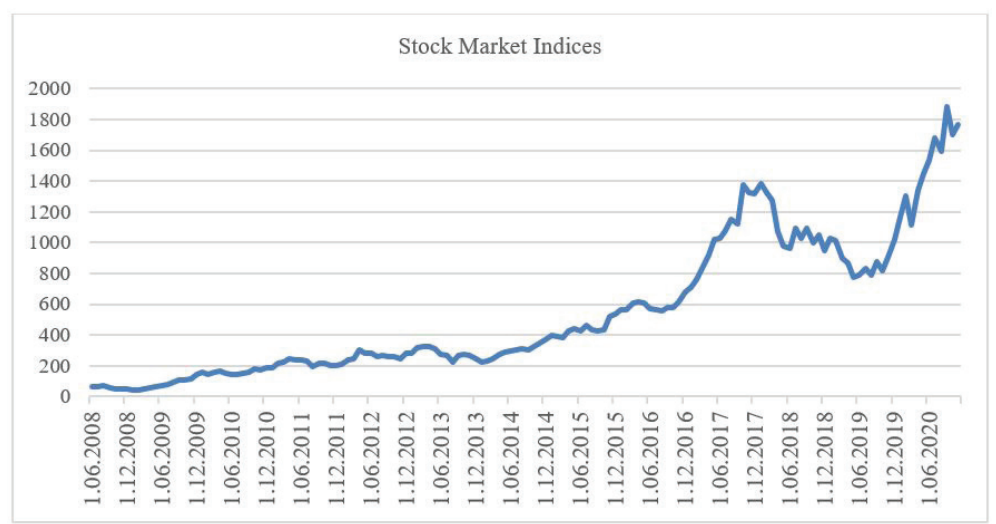

Figure 5. Trend of Exchange Rate

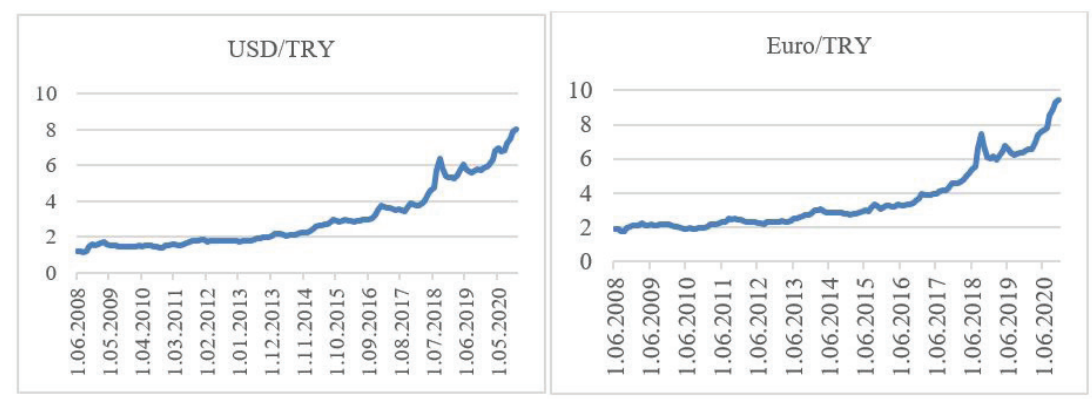

The stock market indices of service and the financial sectors are highly volatile in Fig. 1 and Fig. 2 when compared to the industrial and technology sector in Fig. 3 and Fig. 4 but the volatility of the technology sector against the other three sectors has increased substantially since 2016 . The exchange rate has shown an emerging trend since 2018. Figure 5 shows that the volatility of the USD/TRY exchange rate is similar to the Euro/TRY rate over the years. 
Table 2: Summary Statistics for Logarithmic Variables

\begin{tabular}{|c|c|c|c|c|c|c|}
\hline Variable & & Mean & Std. Dev. & Min & Max & Obs. \\
\hline \multirow[b]{2}{*}{ In $\Delta$ Stock Indices } & overall & \multirow[b]{2}{*}{0.012} & 0.076 & -0.274 & 0.282 & $\mathrm{~N}=596$ \\
\hline & $\begin{array}{l}\text { between } \\
\text { within }\end{array}$ & & $\begin{array}{l}0.006 \\
0.076\end{array}$ & $\begin{array}{c}0.007 \\
-0.268\end{array}$ & $\begin{array}{l}0.021 \\
0.287\end{array}$ & $\begin{array}{c}\mathrm{n}=4 \\
\mathrm{~T}=149\end{array}$ \\
\hline \multirow{3}{*}{ In $\Delta$ USD/TRY Rate } & overall & \multirow{3}{*}{0.012} & 0.037 & -0.086 & 0188 & $\mathrm{~N}=596$ \\
\hline & between & & 0 & 0.012 & 0.012 & $\mathrm{n}=4$ \\
\hline & within & & 0.037 & -0.086 & 0.188 & $\mathrm{~T}=149$ \\
\hline \multirow{3}{*}{ In $\Delta$ Euro/TRY Rate } & overall & \multirow{3}{*}{0.010} & 0.034 & -0.099 & 0.175 & $\mathrm{~N}=596$ \\
\hline & between & & 0 & 0.010 & 0.010 & $n=4$ \\
\hline & within & & 0.034 & -0.099 & 0.175 & $\mathrm{~T}=149$ \\
\hline
\end{tabular}

Table 2 shows that the average changes in stock market indices, USD/TRY rate and Euro/TRY rate between 06/2008 and 11/2020 have values close to each other. We can say that the standard deviation of stock indices is $50 \%$ more than the USD/TRY rate and Euro/TRY rate.

Table 3: Correlation Matrix

\begin{tabular}{|l|c|c|c|}
\hline & $\ln \Delta$ Stock Indices & $\ln \Delta$ USD/TRY Rate & $\ln \Delta$ Euro/TRY Rate \\
\hline $\ln \Delta$ Stock Indices & 1.000 & & \\
\hline $\ln \Delta$ USD/TRY Rate & -0.346 & 1.000 & \\
\hline $\ln \triangle$ Euro/TRY Rate & -0.211 & 0.812 & 1.000 \\
\hline
\end{tabular}

Table 3 provides information on the correlation of variables with each other. While the dependent variable is negatively correlated with the other two independent variables, the results in Table 2 and Table 3 provide preliminary information as summary statistics of variables but should be tested using suitable econometric approaches.

\subsection{Empirical Approach}

In the analysis of the empirical model, the system GMM estimation method is employed, which is re-coded by Roodman (2009) and based on papers by Arellano \& Bover (1995) and Blundell \& Bond (1998). Before analyzing in the static or dynamic panel data models, it should be determined whether there is cross 
section dependence and slope homogeneity. First, cross-sectional dependency is when a shock applied to any unit affects other units as well. Monte Carlo simulations made by Pesaran (2006) indicate that there was significant bias caused by ignoring cross-sectional dependence. Second, the slope coefficient, which varies according to the unit, indicates the panel where there is no homogeneity. Simply put, it might be biased to assume that the exchange rate for all units in the panel affects stock market indices. Also, the assumption of homogeneity prevents the emergence of unit-specific features (Granger, 2003). This study begins by examining whether there is cross-sectional dependence and homogeneity between countries before unit root and regression analysis. Breusch \&Pagan (1980) generated the LM test statistic to examine cross-sectional dependence. The cross-sectional dependency between sectors was detected in the panel and the presence of homogeneity was tested by the test produced by Swamy (1971). The causality relationship was tested with Granger (2003) techniques.

Harris \& Tzavalis (1999) and Breitung \& Das (2005) developed panel unit root tests that consider cross-sectional dependence. Using these tests, we tested whether the series are unit rooted for each panel. To reduce the effect of the correlation between units, IPS (Im, Pesaran \& Shin, 2003), Fisher ADF (Fisher Augmented Dickey Fuller) and Fisher PP (Fisher Philips Perron, 2003) panel unit root tests were applied, which allows series with the difference from cross-section means. Here, there is an alternative hypothesis that not all panels have unit roots, as opposed to the null hypothesis, which maintains that all panels contain unit roots. We also computed cross-sectionally augmented IPS (CIPS) test statistics via the average of individual CADF test statistics for the panel developed by Pesaran (2006).

After understanding the stationarity of the series, we began to decide the specification of the panel data model. Thus, the appropriateness of the estimation of the panel data model with the panel's either fixed effects or random effects model was evaluated with the tests developed by Hausman (1978). The Hausman test result reveals that the fixed effects estimator is valid versus the random effects estimator. However, the traditional fixed effects estimate method produces biased estimators when the past values of the dependent variable are included in 
the model as an independent variable. In dynamic panel data, the current values of the dependent variables cannot be considered independent from their past values and exhibit a dynamic structure. In this study, we have a dynamic panel data model that takes into account the past values of dependent variables. We use robust system GMM methodology that was recommended by Arellano \& Bover (1995) and Blundell \& Bond (1998).

\subsection{Empirical Results}

We used the delta ( $\widetilde{\Delta})$ test proposed by Swamy (1971) to demonstrate the homogeneity or heterogeneity of the slope coefficients. While the alternative hypothesis expresses slope heterogeneity, the null hypothesis states that there is slope homogeneity for all units. Referring to the computed $\widetilde{\Delta}$ results in Table 4, we should carry out homogeneous panel techniques in which the parameters are constant across cross-sections. Also, the results obtained from Table 4 reveal that the analyzed panel data have cross-section dependence.

Table 4: Cross-Sectional Dependence and Homogeneity Tests

\begin{tabular}{|c|c|c|c|}
\hline Test & In $\Delta$ Stock Indices & In $\triangle$ USD/TRY Rate & In $\Delta$ Euro/TRY Rate \\
\hline \multicolumn{4}{|c|}{ Cross sectional dependence tests } \\
\hline \multicolumn{4}{|c|}{ Null: Hypothesis of cross-section independence } \\
\hline CD & $21.43^{*}$ & $29.90^{*}$ & 29.90 \\
\hline \multicolumn{4}{|c|}{ LM test of error cross-section independence } \\
\hline$C D_{L M}$ & $20.3^{*}$ & & \\
\hline $\begin{array}{l}L M \\
L M_{a d j}\end{array}$ & $\begin{array}{l}421^{*} \\
24.08 \\
\end{array}$ & & \\
\hline \multicolumn{4}{|c|}{ Homogeneity tests } \\
\hline$\tilde{\Delta}$ & & $-1.050 *$ & $0.463^{\star}$ \\
\hline Chi2 t-statistic & 8.93 & & \\
\hline
\end{tabular}

Note: *Statistical significance at $1 \%$ level

The time series are stationary if the mean variance and covariance of the time series do not vary over time. Unit root tests are applied to reveal the stationarity of the series. It is appropriate to use the Breusch-Pagan LM test for testing cross-sectional dependence when $\mathrm{T}$ is large and $\mathrm{N}$ is small. In this case, 
the Breusch-Pagan LM test results become important. The Breusch-Pagan LM test shows that there is cross-sectional dependence in the panel time series. Thus, it is necessary to use unit root tests that take into account cross-sectional dependence. Panel data unit root tests are given in four separate classifications, as seen in Table 5. The first method states that each cross section data is based on a common unit root process, and includes the HT test and Breitung test. The second method assumes that each cross section data is in a different unit root process and includes the IPS test, ADF- Fisher test and PP- Fisher test. The third method (MADF test) assumes that enable different integration levels of all series. The fourth method (CIPS-Cross sectionally IPS statistics test) implies that is expanded by taking the cross-sectional averages and modeling the crosssectional dependence with the help of factors.

Table 5: Results from Panel Unit Root Tests

\begin{tabular}{|c|c|c|c|c|c|c|}
\hline \multirow[t]{2}{*}{ Panel Stationarity Tests } & \multicolumn{2}{|c|}{ In $\Delta$ Stock Indices } & \multicolumn{2}{|c|}{ In $\triangle$ USD/TRY Rate } & \multicolumn{2}{|c|}{ In $\triangle$ Euro/TRY Rate } \\
\hline & Statistics & P-value & Statistics & P-value & Statistics & P-value \\
\hline \multicolumn{7}{|c|}{ Null: Panels contain unit roots } \\
\hline $\begin{array}{l}\text { Harris and Tzavalis (HT) } \\
\text { statistics }\end{array}$ & 0.015 & 0.000 & 0.000 & 0.000 & 0.000 & 0.000 \\
\hline Breitung t-statistics & -5.477 & 0.000 & -6.315 & 0.000 & -8.592 & 0.000 \\
\hline \multicolumn{7}{|c|}{ Null: All panels contain unit roots } \\
\hline $\begin{array}{l}\text { Im, Pesaran and Shin } \\
\text { W-statistics }\end{array}$ & -22.129 & 0.000 & & & & \\
\hline $\begin{array}{l}\text { ADF - Fisher Chi-square } \\
\text { statistics }\end{array}$ & 196.110 & 0.000 & & & & \\
\hline \multirow{2}{*}{$\begin{array}{l}\text { PP - Fisher Chi-square } \\
\text { statistics }\end{array}$} & 288.349 & 0.000 & & & & \\
\hline & Statistics & $\begin{array}{l}\text { Critical- } \\
\text { Value }\end{array}$ & Statistics & $\begin{array}{l}\text { Critical- } \\
\text { Value }\end{array}$ & Statistics & $\begin{array}{l}\text { Critical- } \\
\text { Value }\end{array}$ \\
\hline \multicolumn{7}{|c|}{ Null: All 4 time series in the panel are I(1) processes } \\
\hline MADF-statistics & 638.064 & $15.352^{*}$ & & & & \\
\hline \multicolumn{7}{|c|}{ Null: Cross sectional and first difference mean } \\
\hline CIPS- F joint tests & $-6.190 * \star$ & -2.53 & $2.610 * *$ & -2.53 & 2.610 ** & -2.53 \\
\hline
\end{tabular}

Note: Dependent variables is $\ln \Delta$ Stock Indices, ${ }^{* *}$ critical value $<0.01$ and ${ }^{*}$ critical value $<0.05$.

As seen in Table 5, the results of this test are similar. The level series of these variables are stationary. The null hypothesis stating that all variables are unit root is rejected at the $1 \%$ significance level. Some panel stationarity tests could not be 
performed for $\ln \Delta U S D / T R Y R_{\text {Rate }}$ at and $\ln \Delta E$ Euro/TRYRate $e_{i t}$, since all units in the panel have the same time series (lnUSD/TRYRate $i t$ and $\ln \Delta E_{\text {Euro/TRY Rate }}{ }_{i t}$ ).

Table 6 shows the individual output of panel Granger causality tests in homogeneous panel data models. We ran the Granger panel causality test, in which the causality relations of individual variables were considered for the period between 06/2008-11/2020. Table 6 reveals that the panel causality from stock indices variable to the exchange rate (both USD and Euro) variables were found to be insignificant. The panel data reveals significant causality from exchange rates ( $\ln \Delta U S D / T R Y R_{\text {Rate }}$ and $\ln \Delta$ Euro/TRYRate $_{i t}$ ) to stock indices (ln $\Delta$ Stock Indices) as shown in Table 6.

Table 6: Granger Panel Causality Test

\begin{tabular}{|l|c|c|}
\hline Panel Null Hypothesis (No Causality) & Wald Statistic & p-values \\
\hline $\ln \Delta$ Stock Indices $\rightarrow \ln \Delta$ USD/TRY Rate & 0.364 & 0.834 \\
\hline $\ln \Delta$ USD/TRY Rate $\rightarrow \ln \Delta$ Stock Indices & $40.082^{\star}$ & 0.000 \\
\hline $\ln \Delta$ Stock Indices $\rightarrow \ln \Delta$ Euro/TRY Rate & 5.175 & 0.075 \\
\hline $\ln \Delta$ Euro/TRY Rate $\rightarrow \ln \Delta$ Stock Indices & $27.120^{\star}$ & 0.000 \\
\hline
\end{tabular}

Note: Wald Statistic: *Statistical significance at $1 \%$ level

In this paper, the Hausman test was conducted. It can be seen from the results in Table 7 that the null hypothesis was rejected for both $p$-values at 0.00 . The Hausman test reveals that the fixed effects estimator is a suitable estimator at the $1 \%$ significance level. The model with fixed effects estimation method is as Eq. (2)

Table 7: Model Specification Test

\begin{tabular}{|l|c|c|}
\hline Test & Statistics & P-value \\
\hline Hausman & 11.48 & 0.009 \\
\hline
\end{tabular}

$\ln \Delta$ Stock Price $_{i t}=\alpha+\beta_{1} \ln \Delta$ Stock Price it $-1_{1}+\beta_{2} \ln \Delta U S D /$ TRY Rate $_{i t}+\beta_{3} \ln \Delta{\text { Euro } / \text { TRYRate }_{i t}}+\varepsilon_{i t}$ (2)

As is well known, exchange rates are instrumental in the stock market of Turkey. The results in Table 8 confirm its remarkable effect on the return of stock indices. Specifically, our results imply that every $1 \%$ increase in the USD/TRY and Euro/ TRY rates, respectively, is associated with $1.141 \%$ and $0.485 \%$ change in stock 
indices at the $1 \%$ significance level. In addition, the three variables in all models are significant. Notably, $\ln \Delta$ Stock Indices $s_{i t-1}$ and $\ln \Delta U S D / T R Y$ Rate $_{i t}$ negatively affect the stock indices, while $\ln \Delta E$ Euro/TRY Rate $i t$ positively affects the dependent variable.

Table 8: Panel Analysis Results

\begin{tabular}{|c|c|c|}
\hline \multicolumn{3}{|l|}{ Fixed Effects Model } \\
\hline Variables & Coefficients & Std. Error \\
\hline In $\Delta$ Stock Indices ${ }_{\text {it-1 }}$ & $-0.095^{\star}$ & 0.041 \\
\hline $\ln \Delta$ USD/TRY Rate ${ }_{i t}$ & $-1.141^{\star \star}$ & 0.140 \\
\hline In $\Delta$ Euro/TRY Rate it $_{\text {i }}$ & $0.485^{\star \star}$ & 0.144 \\
\hline constant & $0.022^{\star *}$ & 0.003 \\
\hline R-sq & 0.996 & \\
\hline
\end{tabular}

Note: Standard errors ${ }^{*} p<0.05,{ }^{* *} p<0.0$.

Right before the explication of the System GMM results, we began by determining the effectiveness of the estimated model. The Hansen test of over identifying restrictions does not reject the null hypothesis at the 1, 5 and $10 \%$ levels of significance (Table 9), expressing that the instruments used in the model are valid. As stated in the methodology, it is clear that the instruments used are past values of stock market indices. Besides, the test for first-order serial correlation in the residuals $A R(1)$ shows that the null hypothesis of no first-order serial correlation is rejected. First-order serial correlation in the residuals $A R(1)$ are accepted. The AR(1) test calculates first-order autocorrelation, and the AR(2) test calculates second-order autocorrelation. The null hypothesis is established, as there is no autocorrelation. For the efficiency of the GMM estimator, model findings are expected to have first-order negative autocorrelation and not second-order autocorrelation. When $A R(1)$ and $A R(2)$ test statistics and significance values are examined, it is seen that while there is first-order negative autocorrelation, there is no second-order autocorrelation. These diagnostic results reveal that the model specification is acceptable.

According to the estimation results obtained from the model, the lagged value of the dependent variable and have a negative effect on stock indices. $1 \%$ increase 
in the share of and respectively, decreases by $0.091 \%$ and $1.094 \%$ at $\% 5$ and $\% 1$ significance levels. The -Euro/TRY Rate- has a positive effect on stock indices. A $1 \%$ increase in the share of increases by $0.539 \%$ at the $\% 1$ significance level.

Table 9: Results from Panel GMM(Generalized Method of Moments) Estimation Method

\begin{tabular}{|l|c|c|}
\hline Variables & Coefficient & P-value \\
\hline In $\Delta$ Stock Indices $_{\text {it-1 }}$ & -0.091 & 0.029 \\
\hline In $\Delta$ USD/TRY Rate $_{\text {it }}$ & -1.094 & 0.000 \\
\hline In $\triangle$ Euro/TRY Rate $_{\text {it }}$ & 0.539 & 0.000 \\
\hline Observation & 592 & \\
\hline Instrumental number & 4 & 0.057 \\
\hline AR(1), P/value & -1.90 & 0.723 \\
\hline AR(2), P/value & 0.35 & 0.605 \\
\hline Hansen, P/value & 0.27 & \\
\hline
\end{tabular}

Note: Dependent variable: natural logarithm of stock market indices.

While the results of the causality analysis verify the causality from exchange rates to stock market indices, they show that there is no causality from the stock market indices to exchange rates. Looking at the estimation results, we see that there is a positive and significant effect on the Euro/TRY rate on stock market indices. The results are in line with Nieh \& Lee (2001), Elmas \& Esen (2011), Caporale et al. (2014), Barut et al (2017) and Budak et al. (2017), Gazel (2020). Also, according to GMM estimation results, the effect of the USD/TRY exchange rate has a negative sign and is significant on stock market indices. Thus, it is in line with previous research studies (Nieh \& Lee, 2001; Poyraz \& Tepeli, 2014; Caporale et al., 2014; Altınbaş et al., 2015; Yüce Akıncı \& Küçükçaylı, 2016; Belen \& Karamelikli, 2016; Naresh et al., 2018; Eyüboğlu \& Eyüboğlu, 2018) which clearly explain that the exchange rate has a significant effect on the stock market or stock market indices.

\section{Conclusion}

The Balance of Payment Approach, which is a flow-oriented approach, explains the mechanism which changes in value of the domestic currency affect stock prices. When exchange rates increase, the profits of the exporting sectors decrease and the 
stock prices decrease due to the decrease in international competitiveness. The opposite of this situation is expected for sectors with high import rates. The portfolio balance approach, which is a stock-oriented approach, explains the mechanism which changes in stock prices affect exchange rates. In this study, we think it is very important to state that we analyzed the effect of exchange rates on stock prices within the assumptions of the balance of payments approach. The analysis of the effects of USD and Euro exchange rates on stock market indices of four sectors was carried out with the panel data analysis based on the system GMM estimation method. As Naresh et al. (2018) demonstrated in their work, the dynamic panel data models are more appropriate to analyze the relationship between the stock market and exchange rates. The Arellano-Bover/Blundell-Bond estimator is convenient for this analysis. The System GMM method is a general estimator conceived for a log-linear model and includes the past values of the dependent variable that is dependent on a dynamic process in the model. Independent variables that are not entirely exogenous are correlated to the past and current values of the error term. The dynamics estimates of short-run stock market indices based on four sectors over the periods of 06/2008$11 / 2020$ are more notable as they use an instrumental variable.

In this study, we analyzed the effect of exchange rates on the stock market indices in main sectors that reflected the general structure of BIST. GMM estimation results take into account the dynamic relationship that includes the past value of stock market indices which show that there is a positive and significant effect on the Euro/TRY rate on stock market indices. Referring to Turkey's foreign trade statistics (Turkish Statistical Institute, 2021), the Euro is the most used currency unit in payments made for export. The appreciation of the domestic currency against the Euro, that is, the decrease in the exchange rate reduces the international competitiveness of the exporting sectors and reduces their sales. The decrease in the income of the firms in the exporter sectors causes the stock prices of those firms to decrease. Besides, according to GMM estimation results, it is concluded that the effect of the USD/TRY exchange rate has a negative sign and is significant on stock market indices. Also, referring to Turkey's foreign trade statistics (Turkish Statistical Institute, 2021), the USD is the most used currency unit in payments made for import. The increase in the USD/TRY rate 
raises the costs of firms that import intermediate goods. While other conditions are constant, the stock market indices decrease in the sectors that include importing firms. Indeed, the share of intermediate goods imports in total imports was approximately $75 \%$ in 2020 for Turkey. The value of this ratio is generally high between the years 2013-2020. The findings obtained from the analysis results confirm prior knowledge acquired from Turkey's foreign trade structure. The results confirm the hypothesis that the exchange rates (USD/TRY and Euro/TRY) have an effect on stock market indices of four main sectors in Turkey and there is positive causality from the Euro/TRY exchange rate and negatively causality from the USD/TRY exchange rate to the stock market indices in four main sectors in Turkey over the period 06/2008-11/2020.

Considering that firms operating in many sectors in Turkey are affected by the volatility of the exchange rate, this paper is a step towards comprehending how stock market indices of four sectors respond to fluctuation in USD and Euro prices. The findings show that fluctuations in the USD and Euro positively and negatively affect stock market indices, depending on the sector's import and export intensity. This paper has only assessed the effective exchange rates on stock market indices but a potential link between risk, stock market prices and exchange rates was not determined. Thus, more detailed findings may emerge if the extent to which firms are individually affected in a specific sector with a high level of dollarization is analyzed with time series. Also, this study contributes to the further research as it reveals the dynamic effect of exchange rates on stock market indices. Finally, we think that this research helps to deal with all aspects of this issue when we investigate the dynamic effect of stock market indices on exchange rates in the context of the portfolio approach.

The Covid-19 pandemic, which has affected the whole world since the beginning of 2020, is an unprecedented global shock involving simultaneous cuts in both supply and demand in an interconnected world economy. Therefore, future research should analyze the relationship between the exchange rates and the stock market, including the effects of the Covid-19 global pandemic. Studying this phenomenon in conjunction with global shocks can be useful to advance understanding of this phenomenon and generalize research findings. 
Ethics Committee Approval: The study does not require ethics committee approval.

Peer-review: Externally peer-reviewed.

Author Contributions: Conception/Design of Study- H.A.Y., F.G.; Data Acquisition- F.G.; Data Analysis/Interpretation- H.A.Y.; Drafting Manuscript- H.A.Y., F.G.; Critical Revision of Manuscript- H.A.Y., F.G.; Final Approval and Accountability- H.A.Y., F.G.

Conflict of Interest: The authors have no conflict of interest to declare.

Grant Support: The authors declared that this study has received no financial support.

\section{References}

Aggarwal, R. (1981). Exchange rates and stock prices: a study of the US capital markets under floating exchange rates. Akron Business and Economic Review, 12, 7-12.

Akdağ, S., \& Yıldırım, H. (2019). Dolar kuru ile seçilmiş BiST sektör endeksleri arasındaki ilişki: Asimetrik nedensellik analizi. The Academic Elegance, 6(12), 409-425.

Akel, V., \& Gazel, S. (2014). Döviz kurları ile BiST sanayi endeksi arasındaki eşbütünleşme ilişkisi: Bir ARDL sınır testi yaklaşımı. Erciyes University Journal of Faculty of Economics and Administrative Sciences, (44), 23-41.

Altınbaş, H., Kutay, N., \& Akkaya, G.C. (2015). Makroekonomik faktörlerin hisse senedi piyasaları üzerindeki etkisi: Borsa İstanbul üzerine bir uygulama. Journal of Economics and Management Research, 4(2), 30-48.

Arellano, M., \& Bover, O. (1995). Another look at the instrumental variable estimation of errorcomponents models. Journal of Econometrics, 68, 29-51.

Aydemir, O., \& Demirhan, E. (2009). The relationship between stock prices and exchange rates evidence from Turkey. International Research Journal of Finance and Economics, (23), 207-215.

Aydın, M. (2017). Gelişmekte olan ülkelerde borsa ile döviz kurları arasındaki ilişki: simetrik ve asimetrik nedensellik analizi. Journal of Econometrics and Statistics, (27), 1-15.

Ayvaz, Ö. (2006). Döviz kuru ve hisse senetleri fiyatları arasındaki nedensellik ilişkisi. Gazi University Journal of the Faculty of Economics and Administrative Sciences, 8(2), 1-14.

Bahmani-Oskooee, M., \& Sohrabian, A. (1992). Stock prices and the effective exchange rate of the dollar. Applied Economics, 24, 459-464.

Barut, A., Karaoğlan, S., \& Karabayır, M.E. (2017). Faiz oranı-döviz kuru ve BIST100 etkileşimi: Maki eş bütünleşme analizi. Kafkas University Journal of Economics and Administrative Sciences, 8(16), 503-523.

Belen, M., \& Karamelikli, H. (2016). Türkiye'de hisse senedi getirileri ile döviz kuru arasındaki ilişkinin incelenmesi: ARDL yaklaşımı. Istanbul University Journal of the School of Business, 45(1), 34-42.

BIST DataStore (2020). Equity Market Data. Retrieved from https://datastore.borsaistanbul.com/

Blundell, R., \& Bond, S. (1998). Initial conditions and moment restrictions in dynamic panel data models. Journal of Econometrics, 87, 115-143.

Borsa Istanbul (2020). Borsa Istanbul Historic and Reference Data Platform: Equity Market Data. Retrieved from https://datastore.borsaistanbul.com/ Accessed 19 Dec, 2020.

Breitung, J., \& Das, S. (2005). Panel unit root tests under cross-sectional dependence. Statistica Neerlandica, (59), 414-433. 
Bronson, W.H. (1983). A model of exchange - rate determination with policy reaction: evidence from monthly data. NBER Working Paper Series, No:1135, Cambridge.

Budak, S., Cangi, S.Ö., \& Tuna, İ. (2017). Temel makroekonomik değişkenlerin BIST endeksleri üzerindeki etkisi. The Journal of Academic Social Science, (55), 34-42.

Caporale, G., Hunter, J. \& Menla Ali, F. (2014). On the linkages between stock prices and exchange rates: Evidence from the banking crisis of 2007-2010. International Review of Financial Analysis, 33, 87-103.

Central Bank of the Republic of Turkey (2020). Electronic Data Delivery System: BIST Indices and Trading Data. Retrieved from https://evds2.tcmb.gov.tr/ Accessed 19 Dec, 2020.

Central Registry Agency (2021). Yearly Statistics. Retrieved from https://www.mkk.com.tr/tr-tr/VeriDepolama-Hizmetleri/e-VERi/Sayfalar/Yillik-Istatistiki-Veriler.aspx

Cingöz, F., \& Kendirli, S. (2019). Altın fiyatları, döviz kuru ve Borsa İstanbul arasındaki ilişki. Research of Financial Economic and Social Studies, 4(4), 545-554

Department of Strategy \& Budget (2021). Foreign trade and balance of payments. Retrieved from https://www.sbb.gov.tr/cari-denge/

Dornbusch, R., \& Fischer, S. (1980). Exchange rates and the current account. The American Economic Review, 70(5), 960-971.

Dünya (2020). Borsada yabancı payı, 16 yıl sonra \%50'nin altında!. Retrieved from https://www. dunya.com/finans/haberler/borsada-yabanci-payi-16-yil-sonra-50nin-altinda-haberi-474727

Elmas, B., \& Esen, Ö. (2011). Hisse senedi fiyatları ile döviz kuru arasındaki dinamik ilişkinin belirlenmesi; farklı ülke piyasaları için bir araştırma. The Journal of Accounting and Finance, (52), 153-170.

Ersoy H., \& Koy, A. (2016). Euro ve ABD doları kurları ile pay senedi endeksleri arasındaki ilişkinin incelenmesi: Borsa İstanbul verileri üzerine ampirik bir çalışma. Journal of Finance \& Banking Studies, 5(2), 21-36.

Eyüboğlu S., \& Eyüboğlu, K. (2018). Borsa İstanbul sektör endeksleri ile döviz kurları arasındaki ilişkilerin incelenmesi: ARDL modeli. Ömer Halisdemir University Academic Review of Economics and Administrative Sciences, 11(1), 8-28.

Gazel, S. (2020). BRICS ülkelerinde döviz kuru, enflasyon ve hisse senedi piyasası ilişkisi: asimetrik panel nedensellik testi. Doğuş University Journal, 21(1), 21-34.

Görmüş, Ş., Yılancı, V., \& Aydın, M. (2016). Asimetrik panel nedensellik testi: Gelişmekte olan ülkelerin borsaları üzerine bir uygulama. ICPESS, 24-26 August, İstanbul, 377-391.

Granger, C.W.J. (2003). Some aspects of causal relationships. Journal of Econometrics, 112(1), 69-71.

Hatemi-J, A., \& Irandoust, M. (2002). On the causality between exchange rates and stock prices: A note. Bulletin of Economic Research, 54(2), 197-203.

Harris, R., \& Tzavalis, E. (1999). Inference for unit roots in dynamic panels where the time dimension is fixed. Journal of Econometrics, 91(2), 201-226.

Hausman, J. (1978). Specification tests in econometrics. Econometrica, (46), 1251-1271.

Im, K. S., Pesaran, M.H., \& Shin, Y. (2003). Testing for unit roots in heterogeneous panels. Journal of Econometrics, 115, 53-74. 
İlarslan, K. (2018). Kısa ve uzun dönemde döviz kurları ile borsa endeksi arasındaki ilişkinin açıklanmasına yönelik ampirik bir çalışma. Hacettepe University Journal of Economics and Administrative Sciences, 36(1), 83-104.

Kanat, E. (2018). Türkiye'nin teknoloji sektörü ve döviz kurları ile ilişkisi: Borsa İstanbul teknoloji endeksi. Finans Politik \& Ekonomik Yorumlar, (645), 61-74.

Keskin Benli, Y. (2015). Döviz kuru ile borsa istanbul 100 ve sektör endeksleri arasındaki ilişkinin ampirik analizi. Journal of Humanities and Academic Science, 4(12), 55-72.

Kumar, S. (2019). Asymmetric impact of oil prices on exchange rate and stock prices. The Quarterly Review of Economics and Finance, 72, 41-51.

Kutty, G. (2010). The relationship between exchange rates and stock prices: The case of Mexico. North American Journal of Finance and Banking Research, 4(4), 1-12.

Naresh, G, Vasudevan, G., Mahalakshmi, S., \& Thiyagarajan, S. (2018). Spillover effect of US dollar on the stock indices of BRICS. Research in International Business and Finance, 44, 359-368.

Nieh, C.C., \& Lee, C.F. (2001). Dynamic relationship between stock prices and exchange rates for G-7 countries. The Quarterly Review of Economics and Finance, 41, 477-490.

Pesaran, M.H. (2006). Estimation and inference in large heterogeneous panels with a multifactor error structure. Econometrica, 74(4), 967-1012.

Polat, M. (2018). Döviz kurunun firmaların piyasa değerine etkisi: OECD ülkeleri üzerine eşbütünleşme ve nedensellik analizi. Ataturk University Journal of Economics and Administrative Sciences, 32(2), 211-230.

Poyraz, E., \& Tepeli, Y. (2014), Seçilmiş makroekonomik göstergelerin Borsa İstanbul XU100 Endeksi üzerindeki etkisinin analizi. PARADOKS Economics, Sociology and Policy Journal, 11(2), 102-128.

Roodman D. (2009). How to do xtabond2: An introduction to difference and system GMM in Stata. The Stata Journal, 9(1), 86-136.

Tabak, B.M. (2006). The dynamic relationship between stock prices and exchange rates: evidence for Brazil, Banco Central do Brasil Working Paper Series, No:124, Brasilia.

Tian, G.G., \& Ma, S. (2010). The relationship between stock returns and the foreign exchange rate: The ARDL approach. Journal of the Asia Pacific Economy, 15(4), 490-508.

Turkish Statistical Institute (2021). Foreign trade statistics. Retrieved from https://www.tuik.gov.tr/

Uğur A., \& Bingöl, N. (2020). Hisse senedi ve döviz kuru ilişkisinin yönü: Türkiye üzerine bir araştırma. Omer Halisdemir University Academic Review of Economics and Administrative Sciences, 13(4), 624-636.

Uzun U., \& Güngör, B. (2017). Borsa endeksleri ile ülkelerin seçilmiş makroekonomik göstergeleri arasındaki ilişkinin uluslararası boyutta incelenmesi. Bolu Abant İzzet Baysal University Journal of Graduate School of Social Sciences, 17(4), 1-30.

Yıldız, A. (2014). Döviz kuru ile sektörel hisse senedi endeksleri arasındaki ilişki. Finance, Politics and Economic Reviews, 51(593), 77-91.

Yüce Akıncı, G., \& Küçükçaylı, F. (2016), Hisse senedi piyasası ve döviz kuru mekanizmaları üzerine bir panel veri analizi. The Journal of Accounting and Finance, (71), 127-148. 